University of Nebraska - Lincoln

DigitalCommons@University of Nebraska - Lincoln

1991

\title{
Orphaned Mallard Brood Travels Alone from Nest to Water
}

\author{
Gary Krapu \\ USGS Northern Prairie Wildlife Research Center, gkrapu@usgs.gov \\ Christopher Dwyer \\ USGS Northern Prairie Wildlife Research Center \\ Carmen Luna \\ USGS Northern Prairie Wildlife Research Center
}

Follow this and additional works at: https://digitalcommons.unl.edu/usgsnpwrc

Part of the Other International and Area Studies Commons

Krapu, Gary; Dwyer, Christopher; and Luna, Carmen, "Orphaned Mallard Brood Travels Alone from Nest to Water" (1991). USGS Northern Prairie Wildlife Research Center. 62.

https://digitalcommons.unl.edu/usgsnpwrc/62

This Article is brought to you for free and open access by the US Geological Survey at DigitalCommons@University of Nebraska - Lincoln. It has been accepted for inclusion in USGS Northern Prairie Wildlife Research Center by an authorized administrator of DigitalCommons@University of Nebraska - Lincoln. 


\title{
ORPHANED MALLARD BROOD TRAVELS ALONE FROM NEST TO WATER ${ }^{1}$
}

\author{
Gary L. Krapu, Christopher P. Dwyer ${ }^{2}$ AND Carmen R. LunA ${ }^{3}$ \\ U.S. Fish and Wildlife Service, Northern Prairie Wildlife Research Center, \\ Box 2096, Jamestown, ND 58402
}

Key words: Mallard; Anas platyrhynchos; brood; drought; travel; mortality.

Waterfowl young often travel long distances from the nest site to water when accompanied by a parent; the timing of the trip can range from a few hours to days after hatching (Sowls 1955, Bjärvall 1968; Dzubin and Gollop 1972; Ball 1973; Duncan 1983; Afton and Pau-

${ }^{1}$ Received 27 December 1990. Final acceptance 25 February 1991.

${ }^{2}$ Present address: College of Environmental Science and Forestry, State University of New York, Syracuse, NY 13210.

${ }^{3}$ Present address: Arrowwood National Wildlife Refuge, Rural Route 1, Pingree, ND 58476. lus, in press). Little is known, however, of what happens to waterfowl broods or individual young stranded far from water by the death of a parent or after becoming separated or abandoned.

We documented the response of a Mallard (Anas platyrhynchos) brood orphaned at a nest in south-central North Dakota in July 1988 while studying daily survival rates and causes of mortality among Mallard ducklings in prairie pothole habitat. On 16 April 1988, an adult hen Mallard was captured in a decoy hen trap (Sharp and Lokemoen 1987), banded, and fitted with a radio transmitter. The transmitter weighed approximately $23 \mathrm{~g}$ and was attached with a back harness as described by Dwyer (1972). She later nested in tall, dense cattail (Typha spp.) vegetation in a 44-ha dry semipermanent wetland basin (Fig. 1). The last egg of her seven-egg clutch was laid on 5 June; pipping began 


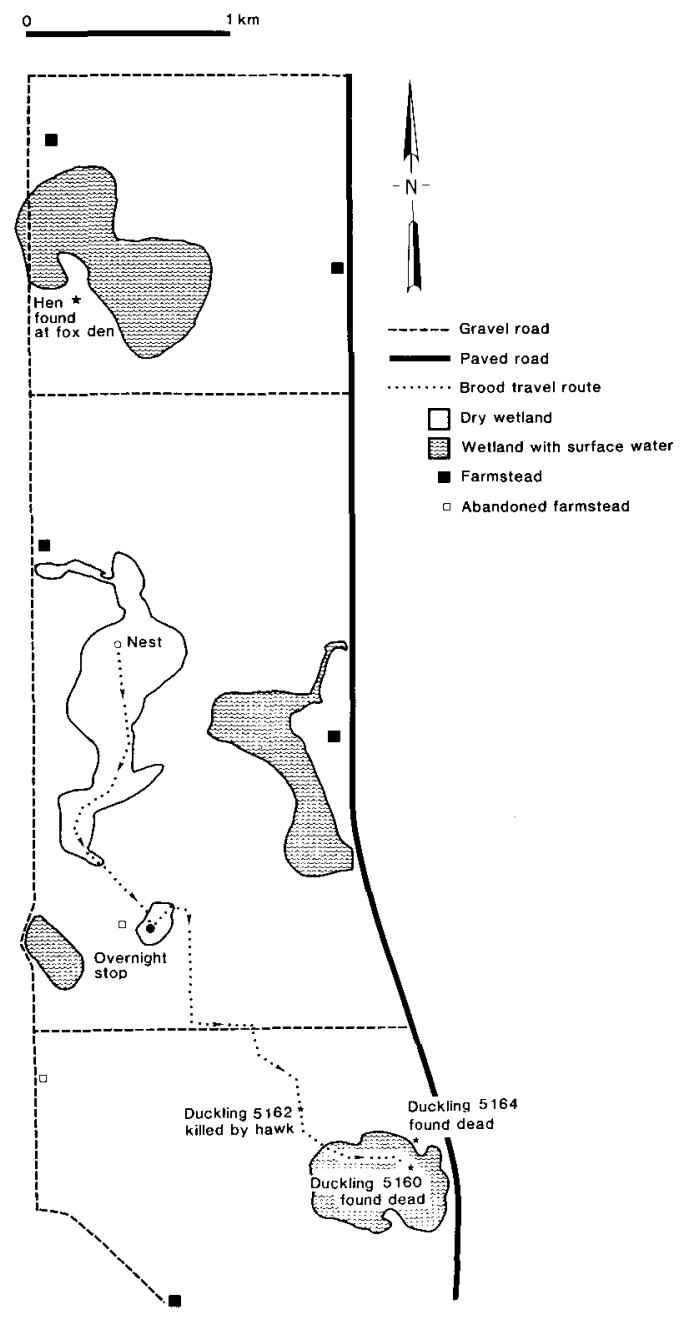

FIGURE 1. Location of Mallard nest, hen remains, and route traveled by brood from the nest to water.

on 1 July and all eggs had hatched by the evening of 2 July. Microtransmitters weighing approximately 2.5 $\mathrm{g}$ each were glued and sutured to the backs of two of the ducklings of the brood. Each duckling in the brood received a uniquely numbered web-tag. We monitored the radio transmitters from the time the ducklings were tagged until they reached water.

A predator killed the hen during the night of 2 July while the ducklings remained in the nest bowl; the brood left the nest in the late afternoon (16:00) of 3 July on a $17.5-\mathrm{hr}, 4.1-\mathrm{km}$ trip to water (Fig. 1). Although the brood was not seen during the trip, several sources of information suggest the ducklings were not accompanied by an adult during and after their departure from the nest. First, we know the mother was not with them. Throughout the ducklings' travel period, the hen's radio signal remained in the vicinity of an active red fox (Vulpes vulpes) den where her remains were found later (Fig. 1). Second, in the course of monitoring the ducklings' movements from nest to water, we observed no adult Mallards or other waterfowl in the vicinity of the brood. Hens are secretive when moving their broods, so lack of an observation does not rule out an adult's presence; however, sparse cover on the pastures the ducklings crossed increased the likelihood of seeing an adult. Third, we saw no adult with the brood after they reached water even though four of the ducklings were sighted. Fourth, with severe drought conditions and limited nesting underway, these ducklings had little chance of linking up with another brood at or near the nest.

The ducklings apparently traveled together during the trip to water. The two radio-tagged ducklings (Nos. 5160 and 5162) had similar signal locations until 5162 was killed by a Swainson's Hawk (Buteo swainsonii) at 10:50 of the second day of travel (Fig. 1). The three non-transmittered ducklings were seen with the remaining radio-tagged duckling on the same afternoon at 16:00 after they reached water. Mallard ducklings will imprint on brood mates during the first three days after hatching (Lickliter and Gottlieb 1986) and brood members show a strong tendency to keep together whether or not a parent is present (Collias and Collias 1956). This may explain why the brood mates did not become separated during the prolonged journey from the nest to water.

Although the ducklings demonstrated the capacity to travel a long distance to reach water in the absence of a parent, there are indications that the ducklings may have been hampered by the lack of maternal care. The brood's late afternoon departure from the nest was atypical but not unprecedented. Among 10 other Mallard broods for which nest departure times were known, eight left the nest in the morning and two later in the day (Gary L. Krapu, unpubl. data). The proportion of Mallard broods that departed during the morning approximates the pattern observed by Bjärvall (1968) in Sweden.

The brood while traveling from the nest to water maintained a rather direct course (Fig. 1), but the entire trip took 10 times longer than the 1.8-hr median of five previously monitored Mallard broods (Gary L. Krapu, unpubl. data). The overnight stay by the brood in a wetland without surface water accounted for much of this difference. The ducklings probably had no visual or auditory cues of the direction to water when leaving the nest, and they did not go to the nearest wetland with water (Fig. 1). However, there may have been cues available later in the journey when closer to their wetland destination. The route taken did not follow a natural drainage and required traversing a steep hill on the morning of 4 July.

Lack of maternal care also may have contributed to low duckling survival. In addition to hawk predation of 5162 , duckling 5160 was found dead in the water on the morning of 6 July; most of the carcass had been eaten apparently by a mink (Mustela vison). Another brood mate, duckling 5164, was found dead near the edge of the wetland on the same morning (Fig. 1). The remaining ducklings in the brood were not seen again.

We thank E. D. Gilbert and R. L. Sanders for assis- 
tance with the field work and P. J. Pietz for providing constructive comments on previous drafts of the manuscript.

\section{LITERATURE CITED}

AfTon, A. D., AND S. L. PAulus. In press. Incubation and brood care of waterfowl. In B.D.J. Batt [ed.], The ecology and management of breeding waterfowl. Univ. of Minnesota Press, St. Paul.

BALL, I. J. 1973. Ecology of duck broods in a forested region of north-central Minnesota. Ph.D.diss., Univ. Minnesota, St. Paul.

BJÄrval, A. 1968. The hatching and nest-exodus behavior of Mallards. Wildfowl 19:70-80.

Collias, N. E., and E. C. Collias. 1956. Some mechanisms of family integration in ducks. Auk 73: 378-400.

DunCAN, D. C. 1983. Extensive overland movement of Pintail, (Anas acuta), brood and attempted predation by hawks. Can. Field Nat. 97:216-217.
DWYer, T. J. 1972. An adjustable radio-package for ducks. Bird Banding 43:282-284.

DzuBin, A., AND J. B. Gollop. 1972. Aspects of Mallard breeding ecology in Canadian parkland and grassland, p. 113-152. In Population ecology of migratory birds. U.S. Fish Wildl. Serv. Wildl. Res. Rep. No. 2.

Lickiter, R., AND G. GotTlieb. 1986.Visually imprinted maternal preference in ducklings is redirected by social interaction with siblings. Develop. Psychol. 19:265-277.

Sharp, D. E., AND J. T. Lokemoen. 1987. A decoy trap for breeding-season Mallards in North Dakota. J. Wildl. Manage. 51:711-715.

Sowls, L. K. 1955. Prairie ducks: a study of their behavior, ecology, and management. Wildl. Manage. Inst., Washington, DC. 